\title{
Pemodelan airtanah dan Neraca Airtanah Dampak Penambangan Batubara Open Pit pada Lipatan Sinklin di Daerah Muara Lawa, Kabupaten Kutai Barat, Provinsi Kalimantan Timur
}

\author{
Shalaho Dina Devy \\ Teknik Pertambangan, Fakultas Teknik, Universitas Mulawarman, Samarinda \\ E-mail: shalaho.d2@gmail.com
}

\begin{abstract}
Changes in land use impacts on groundwater availability both in quality and quantity. Study of geological, hydrogeological conditions, hydrological, hydrogeological boundary conditions contribute to determine the presence of groundwater in the groundwater basin and determine the natural groundwater flow modeling patterns. Location of the study are in Muara Lawa, including the formation Pulaubalang, Pamaluan, and Balikpapan on Lampanan syncline structure. Exploration drilling results indicate, that the hydrogeological study area into the aquifer system of folded sedimentary rocks consisting of seven aquifer layers alternating between akuitar, aquifers, and the base layer in the form of akuiklud. The area bounded by the limits of the model study of surface water in two major rivers, the Lawa River (east) and the Perak River (west), as well as the groundwater divide with the highest head (north and south. The results of the analysis of the type of regional aquifers aquifer models including the category of semi depressed with aquitards dominance in the surface layer. The pattern of groundwater flow and head height can be predicted by modeling using Visual Modflow. There is an increase zone budget is almost five times higher than the natural condition to the active mining conditions, particularly in the green zone, that of the natural conditions of $1,502 \mathrm{~m}^{3}$ day $y^{-1}$ to $12,930 \mathrm{~m}^{3}$ day-1 in the active mining. This is due, in the mining area there is a change in land use and hidrostratigrafi, namely the formation of pits that reach depths of 70 meters.
\end{abstract}

Keywords: syncline, open pit, groundwater flow, zone budget.

\begin{abstract}
Abstrak
Perubahan tata guna lahan berdampak pada ketersediaan airtanah baik secara kualitas maupun kuantitas. Struktur geologi dan aktivitas penambangan batubara open pit sangat mempengaruhi perubahan pola aliran airtanah. Kondisi seperti ini terjadi pada lokasi penambangan batubara open pit yang berada di kecamatan Muara Lawa yang menjadi daerah model penelitian. Secara metodologis, penelitian ini menggunakan kajian pendekatan dari kondisi hidrogeologi, hidrologi, dan kondisi batas hidrogeologi. Hasil dari penelitian menjelaskan, bahwa Formasi yang berkembang daerah penelitian yaitu, terdiri dari Formasi Pulaubalang, Pamaluan, dan Balikpapan dengan struktur Sinklin Lampanan, dengan sumbu sinklin yang membentang dari timur laut menuju ke barat daya. Hasil kajian hidrogeologi terungkap, bahwa daerah penelitian masuk dalam sistem akuifer batuan sedimen terlipat yang terdiri dari tujuh lapisan akuifer yang berselang-seling antara akuitar, akuifer, dan lapisan dasar berupa akuiklud. Daerah model penelitian dibatasi oleh batas air permukaan, yaitu Sungai Lawa dan Sungai Perak, serta batas pemisah airtanah (utara dan selatan). Pada analisis tipe akuifer, daerah model termasuk kategori akuifer semi tertekan dengan dominasi akuitar. Perubahan morfologi dan geologi akibat aktivitas penambangan batubara open pit berpengaruh terhadap perubahan aliran airtanah, antara lain: daerah pit tambang yang mengalami penurunan elevasi sampai $-60 \mathrm{~m}$ dpl dan penambahan elevasi hingga $40 \mathrm{~m}$ pada daerah disposal. Kondisi ini berdampak perubahan pola arah aliran airtanah ke arah pit dan penurunan muka airtanah piezometrik dan kenaikan neraca airtanah hampir lima kali lipat dari kondisi alami ke kondisi penambangan aktif yang disebabkan perubahan tata guna lahan dan hidrostratigrafi. Perubahan-perubahan dampak aktivitas penambangan dapat diprediksi dengan memodelkan menggunakan Visual Modflow.
\end{abstract}

Kata Kunci: sinklin, open pit, aliran airtanah, neraca airtanah, void.

\section{Pendahuluan}

Penambangan batubara open pit merupakan kegiatan yang menyebabkan perubahan tata guna lahan, morfologi, geologi, dan hidrogeologi. Perubahan ini berdampak pada perubahan topografi, perlapisan batuan bawah permukaan, dan akuifer. Penambangan open pit ini mendasarkan pada aktivitas penggalian ke arah vertikal hingga mencapai lapisan endapan batubara yang diinginkan. Salah satu perusahaan yang melakukan penambangan metode ini adalah PT. Trubaindo Coal Mining (PT. TCM). PT. TCM merupakan salah satu pemegang Perjanjian Karya Pengusahaan Pertambangan Batubara (PKP2B) generasi kedua. Perusahaan ini berlokasi di Kabupaten Kutai Barat yang berjarak $323 \mathrm{~km}$ dari Samarinda, ibukota Provinsi Kalimantan Timur (BPS Kubar, 2011). Daerah model penelitian berada di 
Blok Selatan PT. TCM yang berada di kecamatan Muara Lawa, Kabupaten Kutai Barat, Kalimantan Timur.

\section{Metode Penelitian}

Metode penelitian yang diterapkan adalah metode induktif dengan pendekatan analitik, yang terdiri dari kajian kondisi hidrologi, hidrogeologi, perubahan tata guna lahan, dan pemodelan airtanah, khususnya dampak akibat aktivitas penambangan batubara open pit. Selain itu, penelitian ini menggunakan ekperimen semu (Quasi Experiment Research) yang disebabkan banyaknya data primer di lapangan dan bukan hanya menggabungkan teori-teori untuk menarik suatu kesimpulan tertentu. Adapun urutan tahapan-tahapan dari metode penelitian ini meliputi: (1) persiapan; (2) pelaksanaan dan pekerjaan lapangan; (3) pengolahan dan analisis data, analisis data pada studi kasus ini menggunakan perangkat lunak Visual Madflow; dan (5) penyelesaian. Hasil akhir penelitian ini berupa prediksi model airtanah alami dan ketika operasi penambangan.

\section{Hasil dan Pembahasan}

\subsection{Geologi Daerah Model Penelitian}

Van Bemmelen (1949), mengungkapkan, secara fisiografis kutai Barat masuk dalam Zona Cekungan Kutai. Sementara itu, Supriatna dkk. (1995) berpendapat, stratigrafi Cekungan Kutai ditandai oleh beberapa pengendapan formasi batuan dengan pemerian yang khas dari lingkungan daratan hingga laut dangkal.

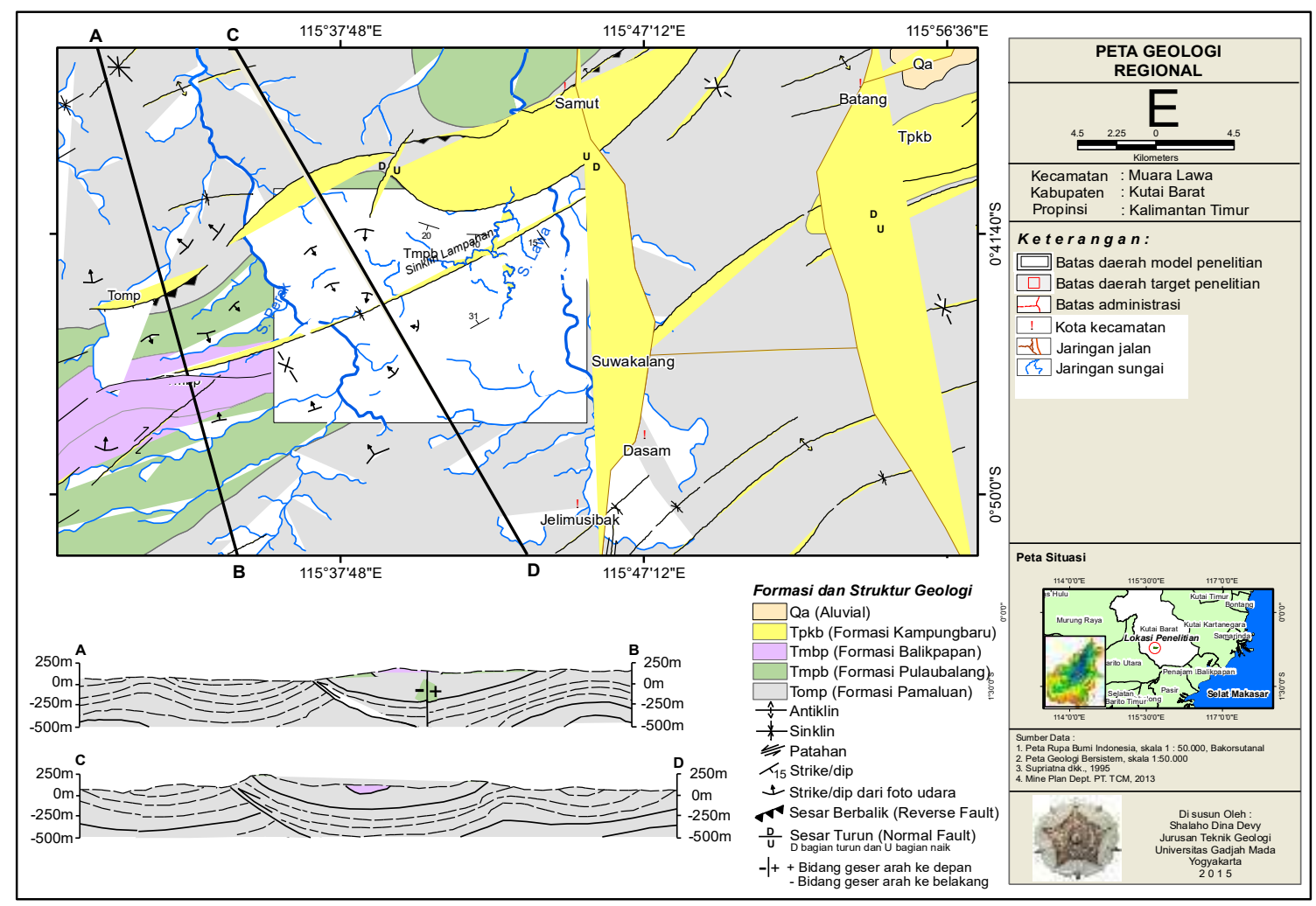

Gambar 1: Peta Geologi Regional Daerah Penelitian

Pada Gambar 1, menjelaskan korelasi dari geologi regional yang dihubungkan hasil pemboran eksplorasi. Stratigrafi daerah penelitian dari paling tua hingga paling muda pada daerah model penelitian terdiri dari: (1) Formasi Pamaluan (Miosen Awal-Miosen Bawah); (2) Formasi Pulaubalang (Miosen Tengah-Miosen Akhir); dan (3) Formasi Balikpapan (Miosen Tengah-Miosen Akhir). Kolom stratigrafinya dapat dilihat pada Gambar 2. 


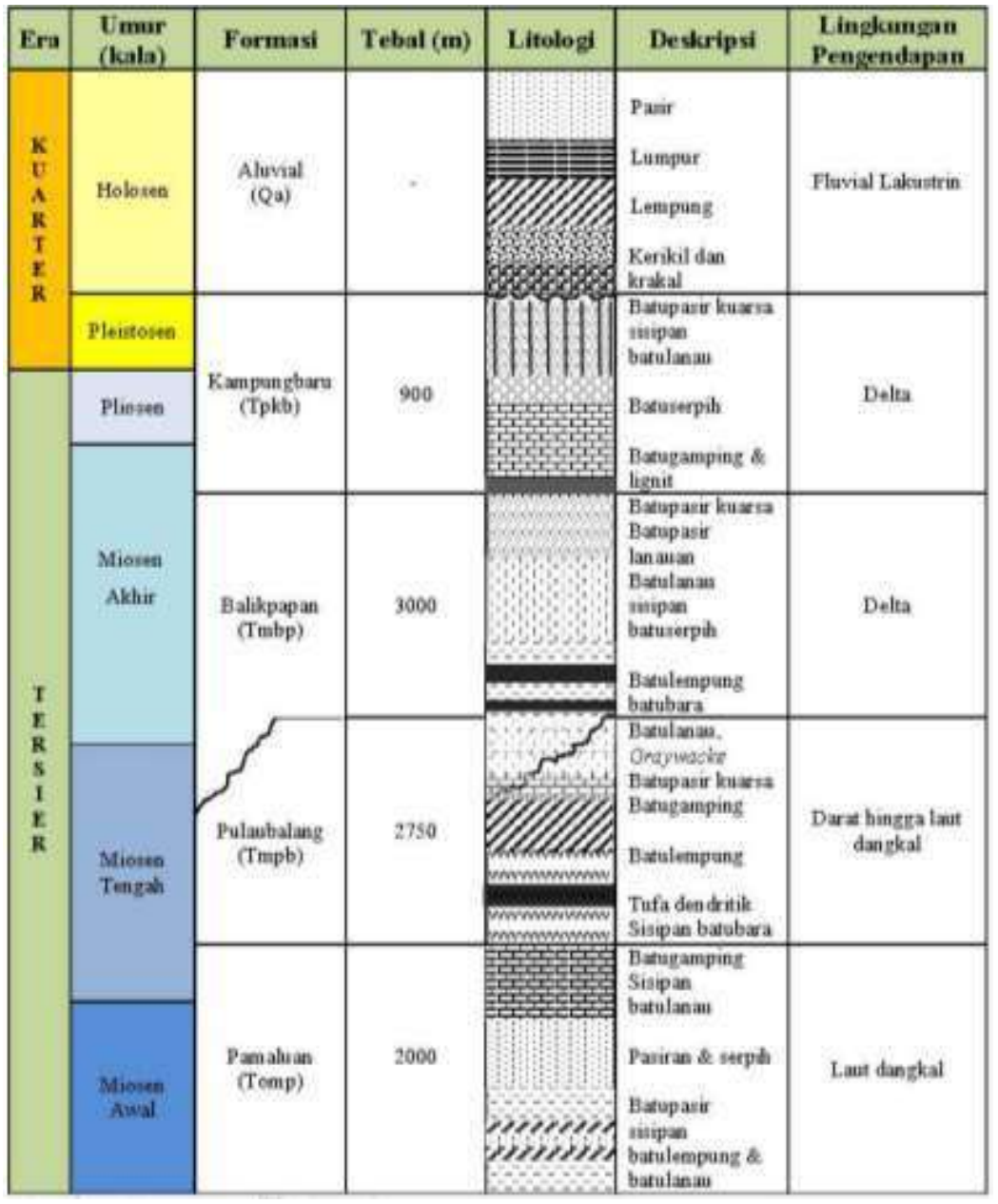

Gambar 2: Kolom Stratigrafi Daerah Penelitian Sumber: Supriatna dkk. (1995)

Secara umum, hasil pemboran ekplorasi lapisan batuan daerah model didominasi oleh batulanau, batupasir, batulempung, dan perselingan batubara dengan ketebalan yang bervariasi. Selain itu, dari ketiga formasi batuan tersebut teridentifikasi satuan-satuan batuan yang mendominasi tiap formasi, yaitu: satuan batulempung (Formasi Pamaluan), satuan perselingan batupasir kuarsa dan batulempung (Formasi Pulaubalang), satuan perselingan batulanau dan batupasir (Formasi Pulaubalang), dan satuan batupasir (Formasi Balikpapan).

Struktur geologi yang berkembang daerah model penelitian berupa lipatan sinklin, yaitu Sinklin Lampanan, yang dipengaruhi oleh fisiografi dari Antiklinorium Samarinda yang terdapat sesar-sesar kecil yang mengakibatkan terjadinya perpotongan perlapisan batuan. Lokasi model penelitian berada ditengah-tengah sumbu lateral sinklin yang membujur diagonal dari arah barat daya ke timur laut. Struktur lipatan sinklin mempunyai arah kemiringan jurus (strike) sebesar $\mathrm{N} 40^{\circ}-50^{\circ} \mathrm{E}$ dengan kemiringan perlapisan (dip) sebesar $16^{\circ}-25^{\circ}$ yang berlokasi sebelah utara. Sementara itu, pada sebelah selatan mempunyai arah strike $\mathrm{N} 180^{\circ}-190^{\circ}$ E dengan dip $20^{\circ}-26^{\circ}$.

\subsection{Hidrologi}

Kondisi hidrologi berperan penting dalam proses penghitungan imbuhan airtanah dan penentu dalam kuantifikasi airtanah. Pemodelan airtanah harus mengenai kondisi daerah imbuhan, konduktivitas akuifer, kondisi batas hidrogeologi. Kapasitas air permukaan sangat dipengaruhi oleh karakteristik kondisi Daerah Aliran Sungai (DAS), tata guna lahan, curah hujan, dan daerah imbuhan. Daerah imbuhan sangat dipengaruhi oleh siklus hidrologi. Faktor penentu besarnya kuantitas imbuhan airtanah 
adalah intensitas hujan. Menurut Mononobe (Kamiana, 2005), nilai intensitas hujan merupakan jumlah hujan pada suatu daerah tiap satuan waktu.

$$
\mathrm{I}=\left(\frac{\mathrm{R}_{24}}{24}\right) \times\left(\frac{24}{\mathrm{~T}_{\mathrm{c}}}\right)^{2 / 3}
$$

Besaran nilai intensitas hujan (I) pada Daerah Aliran Sungai (DAS) sangat dipengaruhi oleh waktu konsentrasi $\left(\mathrm{T}_{\mathrm{c}}\right)$ dari hujan yang merata di seluruh daerah DAS. Waktu konsentrasi adalah waktu perjalanan yang diperlukan oleh air dari tempat yang paling jauh (hulu DAS) sampai ke titik pengamatan aliran air. Secara rinci, rumus waktu konsentrasi $\left(\mathrm{T}_{\mathrm{c}}\right)$ dapat dilihat di bawah ini (Hammer \& Mac Kichan, 1981).

$$
\mathrm{T}_{\mathrm{c}}=\frac{\mathrm{L}}{\mathrm{V}}
$$

Keterangan $T_{c}$ adalah waktu konsentrasi (menit), $L$ atau jarak maksimum aliran DAS (m), V merupakan kecepatan aliran $\left(\mathrm{km} \mathrm{jam}^{-1}\right)$, dan $\mathrm{H}$ merupakan beda tinggi daerah hulu dengan lokasi yang ditinjau $(\mathrm{km})$.

Pada kondisi alami, daerah resapan air tanah sangat dipengaruhi oleh jumlah limpasan air permukaan. Rumus yang digunakan untuk menghitung volume air limpasan ke Metode Departemen Konservasi Tanah Service (SCS) Amerika Serikat ditunjukkan pada Persamaan 3 (Hammer \& Mac Kichan, 1981).

$$
Q=\frac{(P-0,2 S)^{2}}{(P+0,8 S)}
$$

Keterangan, $\mathrm{P}$ adalah curah hujan, dan $\mathrm{S}$ adalah retensi potensial maksimum, semua dalam satuan $\mathrm{mm}$. Nilai retensi potensial maksimum (S, mm) dapat dikorelasikan dengan Persamaan 4.

$$
\mathrm{S}=\frac{25400}{\mathrm{CN}}-254
$$

Sementara itu, untuk menghitung evapotranspirasi nyata dengan metode Thornthwaite yang mengacu pada Persamaan 5 (Seiler \& Gat, 2007).

$$
\mathrm{ET}_{\mathrm{r}}=\frac{\mathrm{P}}{\sqrt{0,9+\frac{\mathrm{P}^{2}}{\left(300+25 \cdot \mathrm{T}_{\mathrm{m}}+0,05 \cdot \mathrm{Tm}^{3}\right)^{2}}}}
$$

Keterangan Persamaan 5 sebagai berikut; $\mathrm{ET}_{\mathrm{r}}$ : evapotranspirasi nyata $(\mathrm{mm} / \mathrm{tahun})$; P: curah hujan (mm/tahun); $\mathrm{T}_{\mathrm{m}}$ : temperatur rata-rata tahunan $\left({ }^{\circ} \mathrm{C}\right)$. Menurut Lerner (1990), metode perhitungan imbuhan airtanah untuk daerah tropis dengan curah hujan tinggi menggunakan rumus sebagai berikut;

$$
\mathrm{U}=\mathrm{P}-\mathrm{ET}_{\mathrm{r}}-\mathrm{Ro}
$$

Keterangan Persamaan 6, sebagai berikut; U: imbuhan airtanah (mm/tahun); P: curah hujan tiap tahun (mm/tahun); $\mathrm{ET}_{\mathrm{r}}$ : evapotranspirasi nyata (mm/tahun); Ro: air limpasan akibat efek dari impermeabialitas tanah (mm/tahun). Hasil perhitungan imbuhan airtanah kondisi alami dapat dilihat pada Tabel 1.

Tabel 1: Prediksi Imbuhan Airtanah Daerah Model Penelitian Pada Kondisi Alami

\begin{tabular}{lcl}
\hline \multicolumn{1}{c}{ Parameter } & Total & Satuan \\
\hline Curah hujan $(\mathrm{P})$ & $2.665,1$ & $\mathrm{~mm} \mathrm{th}^{-1}$ \\
Evapotranspirasi aktual $\left(\mathrm{ET}_{\mathrm{r}}\right)$ & $1.180,5$ & $\mathrm{~mm} \mathrm{th}^{-1}$ \\
Limpasan air permukaan (Ro) & 549,33 & $\mathrm{~mm} \mathrm{th}^{-1}$ \\
Imbuhan airtanah (R) & $\mathbf{9 3 5 , 2 7}$ & $\mathrm{mm} \mathrm{th}^{-1}$ \\
\hline
\end{tabular}




\subsection{Hidrogeologi Daerah Model Penelitian}

Hidrogeologi daerah penelitian ditentukan oleh litologi, keterdapatan sumber air, dan karakteristik akuifer. Berdasarkan klasifikasi Mandel dan Shiftan (1981) dan oleh Puradimadja (1993) disesuaikan dengan kondisi geomorfologi dan geologi indonesia, maka daerah penelitian termasuk dalam Sistem Akuifer Batuan Sedimen Terlipat (Irawan \& Puradimaja, 2013). Sedimen terlipat merupakan lapisan sedimen yang dipengaruhi struktur perlipatan.

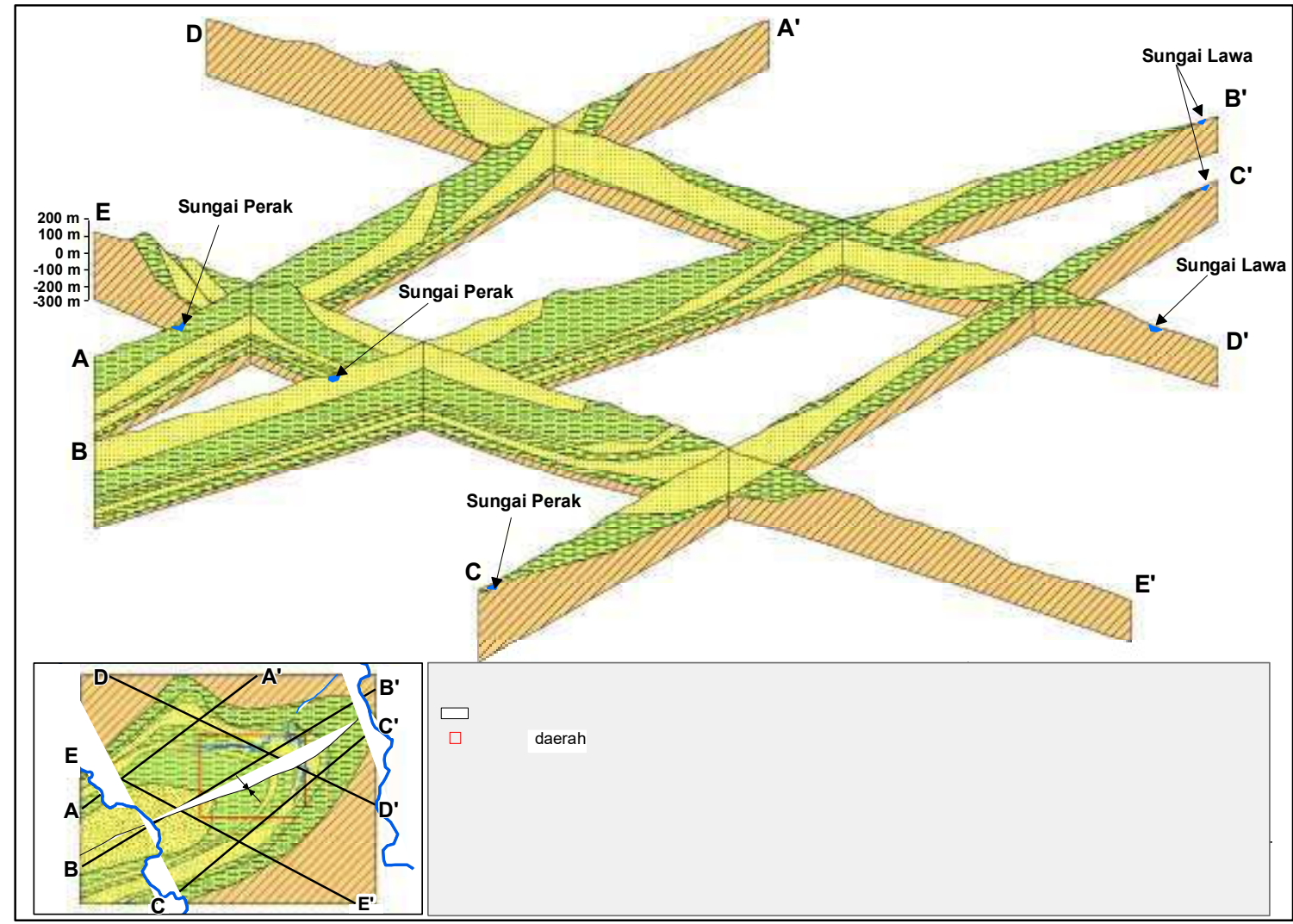

Gambar 3: Hidrogeologi Daerah Penelitian

Daerah model penelitian memiliki dua jenis media akuifer, yaitu akuifer media rekahan dan pori. Akuifer media rekahan dijumpai pada lapisan batubara yang tersisipi pengotor yang membentuk retakan-retakan batubara (cleat) yang berfungsi sebagai tempat aliran airtanah. Retakan-retakan ini membentuk rangkaian retakan yang sejajar yang biasanya berorientasi tegak lurus perlapisan. Pengotor yang menyisipi rekahan terdiri dari unsur mineral atau karbonat, lempung, jenis sulfida atau sulfat yang secara umum nampak pada permukaan batubara yang mengelupas. Sementara itu, akuifer media pori banyak dijumpai pada batupasir dengan rongga-rongga antar butir yang rapat yang berfungsi sebagi media aliran airtanah.

Pengamatan karakteristik airtanah dapat dilakukan berdasarkan pengamatan pada lokasi kemunculannya di permukaan yang berupa munculnya mata air (artesis) dari bekas sumur bor. Tipe mata air yang berkembang di daerah penelitian adalah mata air rekahan (fracture artesian springs) pada perpotongan lapisan batupasir dengan batulanau/batulempung/batubara, serta lapisan batulanau pasiran/batupasir lanauan.

Deformasi yang berupa lipatan sinklin, membentuk akuifer batuan sedimen terlipat yang berakibat kecilnya potensi airtanah di daerah penelitian. Di sisi lain, batuan penyusun yang didominasi oleh batulanau, batulempung pasiran, dan batubara yang mempunyai sifat semi kedap air, menambah makin kecilnya potensi airtanah yang ada. Hasil interpretasi dan analisis log pemboran, uji pemompaan disimpulkan, bahwa lapisan akuifer, yang berfungsi sebagai lapisan pembawa air, dibatasi dan ditutupi 
oleh lapisan penyekat pada bagian atas oleh batuan yang relatif bersifat semi kedap/semi permeabel, yaitu lapisan batulanau. Keterdapatan batupasir yang mayoritas berupa sisipan yang sangat kompak dan berumur tua sebagi akibat dari proses tektonik menyebabkan lapisan batupasir ini kemungkinan kecil berfungsi sebagai akuifer yang potensial (tinggi).

Kedalaman akuifer semi tertekan mempunyai kedalaman yang bervariasi, namun akuifer yang berpotensi sebagai akuifer produktif dikelompokkan menjadi dua, yaitu (1) akuifer kedalaman kurang dari $40 \mathrm{~m}$, dan (2) akuifer dengan kedalaman lebih dari $40 \mathrm{~m}$. Kedalaman akuifer kurang dari $40 \mathrm{~m}$ berada di daerah akuifer atas yang tersebar dari utara pada dataran dan punggung/sayap sinklin sampai ke selatan daerah penelitian. Sementara itu, akuifer kedalaman di atas $40 \mathrm{~m}$ menempati wilayah tengah daerah penelitian pada bagian bawah poros/sumbu sinklin. Ketebalan akuifer yang relatif besar pada bagian tengah lipatan dan mempunyai penyebaran yang luas memberikan cadangan airtanah yang baik. Walaupun demikian, hal ini sangat dipengaruhi juga oleh jumlah imbuhan airtanah yang masuk ke dalam akuifer.

\subsection{Model Konseptual Daerah Model Penelitian}

Model konseptual adalah representasi sederhana dari model alami dari sistem hidrogeologi fisik dan perilaku hidrolik. Model ini merupakan dasar dari model analitik dan numerik yang diformulasikan untuk meniru kondisi asli di lapangan. Model mendasarkan pada kondisi alami daerah penelitian, dan faktor-faktor yang mempengaruhi aliran airtanah, baik disebabkan oleh keadaan alami, seperti: daerah imbuhan, luahan, presipitasi, evapotranspirasi, pola aliran air (permukaan dan airtanah), dan akibat adanya kegiatan yang dapat merubah kondisi alami tersebut, misalnya dampak aktivitas penambangan open pit.

Daerah imbuhan airtanah daerah penelitian meliputi lapisan akuifer yang tersingkap di permukaan. Litologi lapisan akuifer didominasi oleh batupasir yang disisipi oleh batulanau pasiran, pasir, dan batubara. Fluktuasi imbuhan airtanah sangat dipengaruhi oleh besaran presipitasi di daerah penelitian. Sumber airtanah berasal dari air permukaan pada daerah rawa, jaringan sungai-sungai yang berada di daerah lapisan akuifer.

Pada Gambar 4, merupakan deskripsi daerah imbuhan dan daerah luahan airtanah daerah model penelitian. Daerah imbuhan digambarkan dengan poligon warna kuning dan daerah luahan poligon selain warna kuning. Berdasarkan sayatan $\mathrm{A}-\mathrm{A}^{\prime}$ yang memotong tegak lurus dari struktur sinklin memperlihatkan bentuk dari lapisan imbuhan mengikuti lapisan akuifer. Begitu pula daerah imbuhan pada lapisan akuifer yang terlihat di sayatan B-B'. 


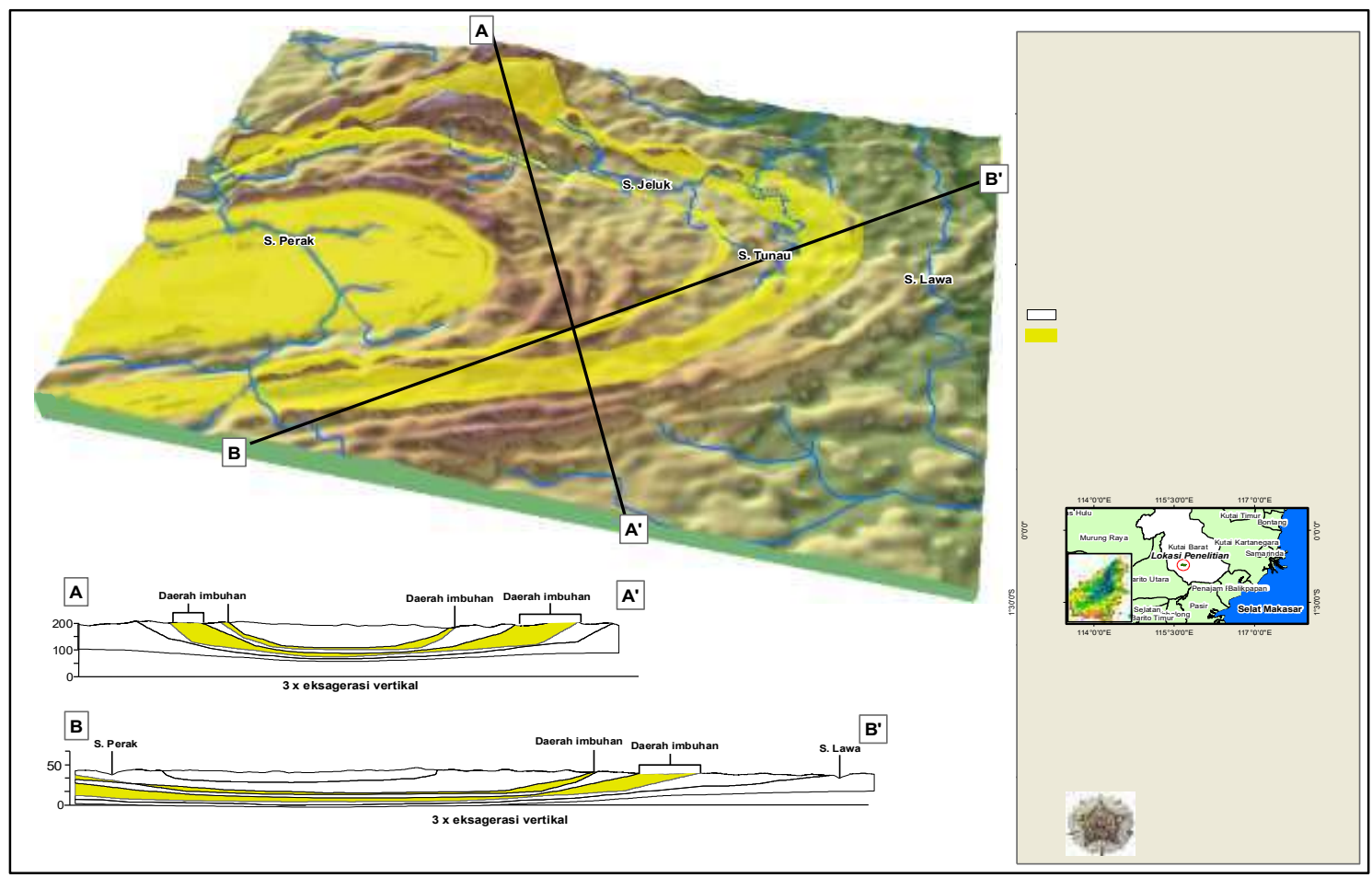

Gambar 4: Daerah Imbuhan dan Luahan Daerah Penelitian

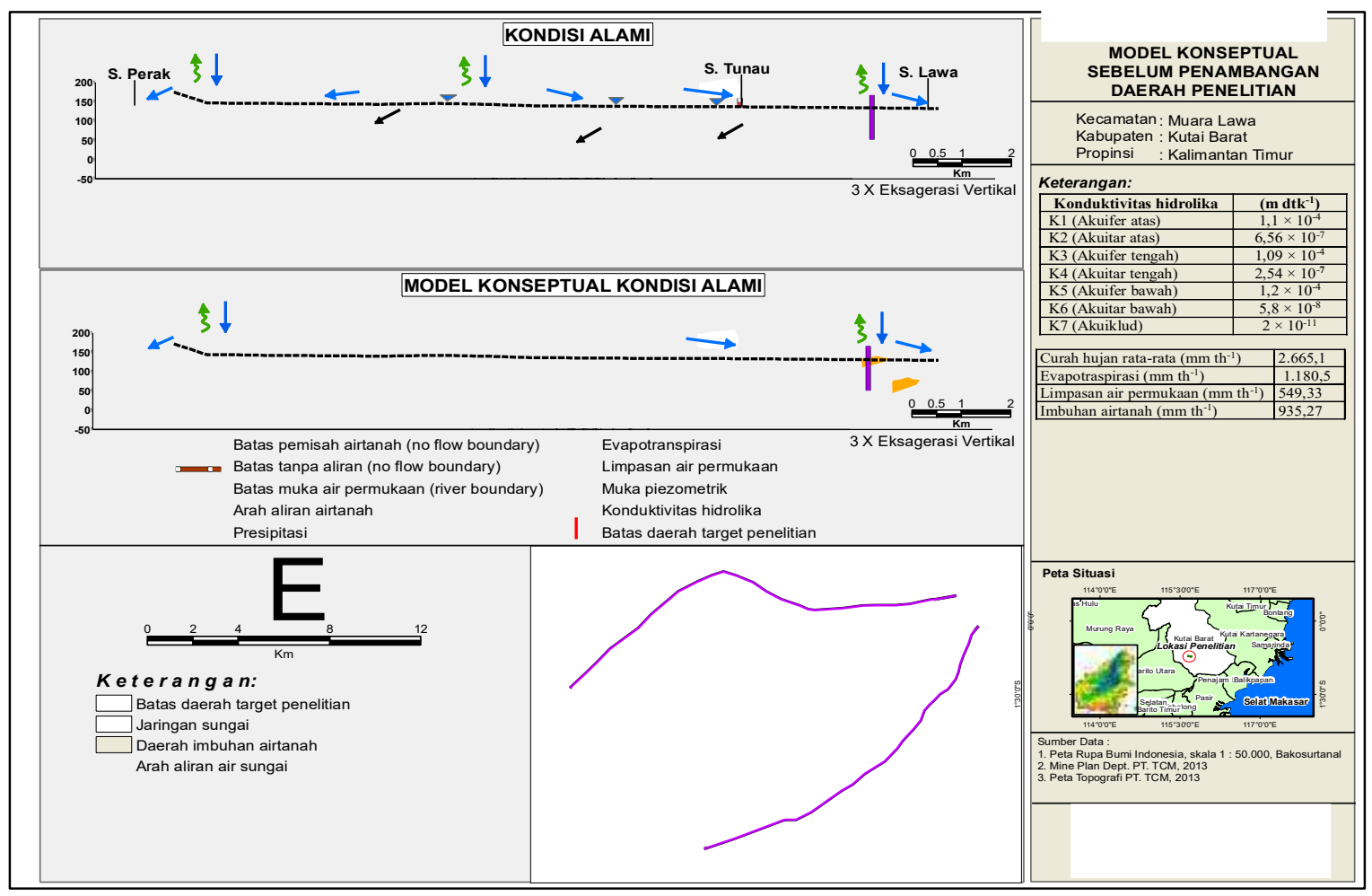

Gambar 5: Model Konseptual Sebelum Penambangan (Kondisi Alami) Daerah Penelitian

Gambar 5 merupakan model konseptual kondisi alami daerah model penelitian. Kondisi batas hidrolika yang menjadi batas hidrogeologis daerah model penelitian bagian permukaan meliputi: (1) batas pemisah airtanah (groundwater divide) berada di daerah pegunungan bagian utara, dan selatan, (2) batas muka air permukaan internal (internal head controlled boundary) yang ditandai dengan keberadaan 
sungai Lawa di timur dan sungai Perak di sebelah barat daerah model penelitian, dan (3) batas aliran airtanah ke luar (outflow boundary) di daerah barat dari daerah model penelitian yang dibatasi oleh sungai Perak. Selain batas permukaan, terdapat kondisi batas hidrolika secara vertikal antara lain: (1) batas tanpa aliran (internal zero-flow boundary) yang berada di bawah lapisan akuiklud dari satuan batulempung formasi Pamaluan, (2) batas sisi timur berupa batas air permukaan internal (internal head controlled boundary) yang ditandai dengan keberadaan sungai seperti sungai Lawa, Perak, Jeluk dan Tunai, dan (3) batas sisi utara dan selatan berupa batas pemisah airtanah (groundwater divide) yang berada pada puncak pegunungan.

\subsection{Penambangan Batubara Open pit Daerah Model Penelitian}

Metode penambangan open pit merupakan kegiatan pengambilan bijih/batubara melalui pengupasan tanah/batuan penutup yang berada di atasnya dan berhubungan langsung dengan udara terbuka. Perubahan litologi akibat penambangan open pit berdampak terganggunya akuifer, misalnya terjadi perubahan muka airtanah, pola aliran airtanah, kualitas-kuantitas airtanah dan sumber airtanah. Di samping itu, terganggunya akuifer mengakibatkan terbentuknya void atau pit lakes akibat lubang bekas pit yang terisi oleh air (permukaan dan airtanah).

Pada perencanaan penambangan, pit tambang mempunyai elevasi terendah mencapai -60 m. Selain itu, terdapat kenaikan elevasi pada daerah disposal dengan kenaikan hingga $30 \mathrm{~m}$. Penurunan elevasi dari pit menyebabkan terpotongnya lapisan pembawa air potensial (akuifer). Kondisi ini makin terlihat apabila elevasi bottom layer dari void menembus lapisan akuifer yang menyebabkan masuknya aliran airtanah ke dalam pit. Semakin dalam pit, maka beresiko terhadap masuknya airtanah yang berkonsekuensi tidak ditambangnya batubara potensial karena tenggelam atau membentuk void.

\subsection{Pemodelan Airtanah dan Zona Neraca Airtanah pada Kondisi Alami Daerah Model Penelitian}

Pemodelan airtanah digunakan untuk mensimulasi dan memprediksi kondisi akuifer dan perubahannya. Manfaat dari pemodelan ini adalah untuk mempresentasikan keadaan airtanah, seperti pola aliran airtanah, kuantitas, dan kualitas airtanah, pada waktu sekarang dan akan datang, khususnya dampak penambangan batubara open pit. Pemodelan airtanah daerah penelitian sangat dipengaruhi oleh kondisi: litologi/akuifer dan geometrinya, head hidrolika, batas hidrogeologis, serta diskretisasi model. Pemodelan pada penelitian ini menggunakan perangkat lunak Visual Modflow.

Pemodelan airtanah diawali dengan pengumpulan data-data mengenai kondisi geologi dan hidrologi pada cekungan airtanah. Pada penelitian ini digunakan metode numerik dengan pendekatan metode beda hingga (finite difference). Metode ini didasarkan dalam membagi daerah model dengan wilayah-wilayah domain dengan grid seragam yang disebut sebagai diskretisasi model. Aspek mendasar model numerik adalah representasi sistem hidrogeologi dengan cara mendiskretisasi model dengan dimensi tertentu. Diskretisasi daerah model penelitian menggunakan bentuk ortogonal grid dengan metode beda hingga (finite difference). Keakuratan dalam analisis dipengaruhi oleh ketelitian dalam penentuan dimensi grid yang mewakili tiap kondisi batas hidrolika/hidrogeologi dan geologi, seperti batas muka air dan struktur batuan.

Pola aliran airtanah sangat dipengaruhi oleh lapisan litologi dan struktur dari batuan. Data-data mengenai batas-batas hidrologi, seperti head air permukaan, lapisan kedap (impermeable), daerah tanpa aliran (no flow); tata guna lahan atau pemanfaatan lahan untuk kegiatan tambang, data meteorologi dan kontur permukaan merupakan data-data pelengkap dalam memodelkan pola aliran permukaan secara konseptual.

Zone groundwater budget atau zona neraca airtanah merupakan kapasitas/kuantitas air yang terdapat dalam akuifer yang berasal dari neraca airtanah pada suatu zona/daerah yang mencakup komponen aliran dari daerah berdekatan dan lapisan-lapisan akuifernya. Pada hasil pemodelan komponen aliran ini merupakan aliran masuk dan keluar dalam suatu zona, seperti constant head, drains, recharge, evapotranspirasi, river leakage, stream leakage, dan general head. Zona neraca airtanah kondisi alami 
digunakan sebagai referensi perubahan zona neraca airtanah pada perubahan tata guna lahan dan hidrogeologi daerah penelitian dampak penambangan open pit.

Setelah ditentukan kondisi batas-batas hidrolika, yang telah diuraikan sebelumnya, kemudian ditentukan nilai dari data-data masukan untuk pemrograman yang didasarkan pada batas konseptual model. Konduktivitas hidrolika batuan (K) dihasilkan dari uji akuifer dengan metode uji pemompaan dan uji slug yang dilakukan pada 9 lokasi bekas lubang pemboran. Selain itu, dilakukan pula pengamatan muka airtanah piezometrik beserta head hidrolika dari 9 lubang bor bekas pemboran tersebut.

Data-data masukan yang diperlukan untuk pemodelan, yaitu batas daerah imbuhan, data sifat lapisan batuan/akuifer, data storativitas batuan/lapisan akuifer, data konduktivitas hidrolika (K), dan ketinggian head hidrolika. Secara singkat, nilai K batuan untuk data masukan dapat dilihat pada Tabel 2, serta kedalaman muka airtanah piezometrik dan head hidrolika observasi/kalibrasi pada Tabel 3.

Tabel 2: Data Masukan Pemodelan Aliran Airtanah Daerah Model Penelitian Kondisi Alami (Kalibrasi)

\begin{tabular}{lccc}
\hline \multicolumn{1}{c}{ Data } & Unit & Nilai & Lokasi \\
\hline K (konduktivitas hidrolika) & $\mathrm{m} \mathrm{det}^{-1}$ & $1,1 \times 10^{-4}$ & Akuifer atas (K1) \\
& & $6,56 \times 10^{-7}$ & Akuitar atas (K2) \\
& & $1,09 \times 10^{-4}$ & Akuifer tengah (K3) \\
& & $2,54 \times 10^{-7}$ & Akuitar tengah (K4) \\
& & $1,2 \times 10^{-4}$ & Akuifer bawah (K5) \\
- Constant head & & $2,8 \times 10^{-8}$ & Akuitar bawah (K6) \\
- River, stream & $\mathrm{m}$ & $170-210$ & Akuiklud bawah (K7) \\
& $\mathrm{m}$ & $60-70$ & Batas pemisah airtanah \\
- Imbuhan airtanah & & $40-70$ & Sungai Lawa \\
& & $60-70$ & Sungai Perak \\
& & & Rawa, Sungai Jelau dan Tunau \\
\hline
\end{tabular}

Tabel 3: Nilai Head Hidrolika Observasi dan Kalibrasi Pemodelan Airtanah Kondisi Alami

\begin{tabular}{cccccc}
\hline No & $\begin{array}{c}\text { Sumur bor } \\
\text { bekas } \\
\text { pemboran }\end{array}$ & $\begin{array}{c}\text { Elevasi } \\
\text { permukaan } \\
\text { (m dpl) }\end{array}$ & $\begin{array}{c}\text { Kedalaman muka } \\
\text { airtanah } \\
\text { piezometrik }(\mathbf{m})\end{array}$ & $\begin{array}{c}\text { Head- } \\
\text { observasi } \\
\text { (m dpl) }\end{array}$ & $\begin{array}{c}\text { Head- } \\
\text { pemodelan } \\
\text { (m dpl) }\end{array}$ \\
\hline 1 & OW-1 & 168 & 58,8 & 107 & 109,2 \\
2 & OW-2 & 136,5 & 37,4 & 97,5 & 99,1 \\
3 & DD 13G & 143,2 & 47,5 & 93 & 95,7 \\
4 & OW-4 & 139,2 & 38,6 & 99 & 100,6 \\
5 & OW-6 & 139,9 & 40,8 & 97,2 & 99,1 \\
6 & OW-8 & 140,8 & 45,8 & 92 & 95 \\
7 & OW-9 & 141,6 & 45,5 & 98 & 96,1 \\
8 & OW-10 & 127,1 & 33,5 & 95,1 & 93,6 \\
9 & OW-13 & 109,2 & 19,2 & 94,2 & 90 \\
\hline
\end{tabular}

Hasil pemodelan mengenai perubahan ekuipotensial head dan arah aliran airtanah sebelum penambangan (kondisi alami) hasil kalibrasi dapat dilihat pada Gambar 6. 


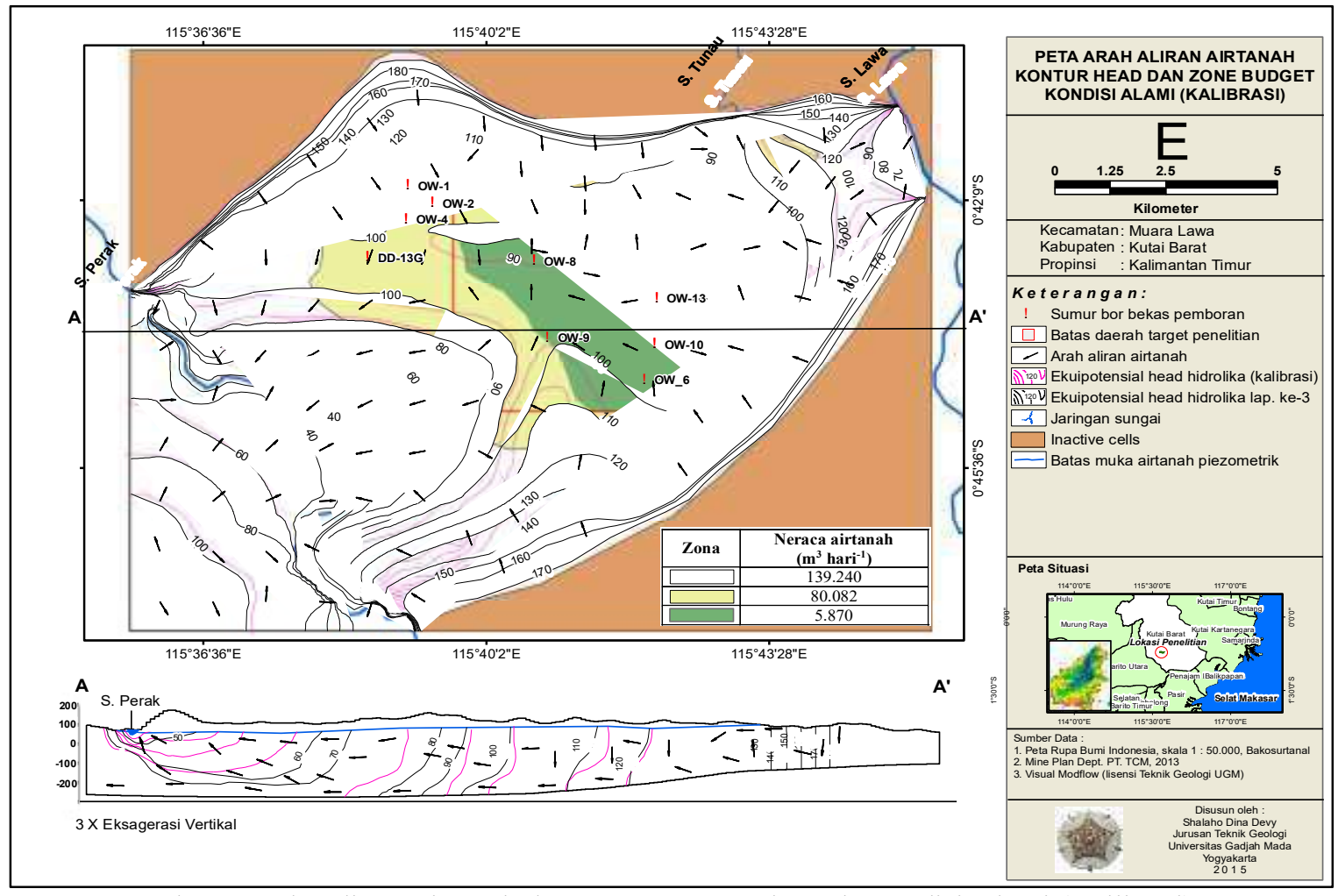

Gambar 6: Pola Aliran Airtanah dan Zona Neraca Airtanah Kondisi Alami (

Hasil pemodelan dengan Visual Modflow, seperti terlihat pada Gambar 6, dapat disimpulkan, nila1 head hidrolika kondisi alami daerah penelitian mempunyai hasil bervariasi dengan tinggi maksimum $210 \mathrm{~m}$ dpl dan minimum $40 \mathrm{~m}$ dpl. Head hidrolika tinggi berada di daerah batas pemisah airtanah yang berupa perbukitan utara dan selatan serta head hidrolika rendah berada di rawa, Sungai Tunau, Jelau, Perak, dan Lawa. Penyebaran ekuipotensial head hidrolika secara rata-rata dari elevasi tinggi di daerah utara, selatan, dan timur, kemudian menuju ke elevasi rendah daerah barat, di Sungai Perak. Pola sebaran ekuipotensial head hidrolika pada lapisan akuifer teratas menggambarkan, ekuipotensial head hidrolika makin turun dan rapat ketika mencapai jaringan sungai, seperti Sungai Tunau dan Jelau. Kerapatan menurun ini menyebabkan aliran airtanah pada lapisan akuifer teratas mengalir menuju ke sungai yang mempunyai head hidrolika rendah dengan kuantitas terbatas. Jadi, akibat kondisi tersebut dapat disimpulkan, airtanah menjadi pengisi/pemberi air pada aliran air sungai atau sebagai gaining stream/effluent.

Zona neraca airtanah alami daerah model penelitian (Gambar 6) dibagi menjadi tiga zona, yaitu pertama, zona putih yang meliputi batas Sub DAS Tunau dan Jelau dengan batas hidrogeologis (daerah perbukitan utara dan selatan serta daerah Sungai Perak dan Lawa), dengan besar neraca airtanah $139.240 \mathrm{~m}^{3}$ hari-1. Kedua, zona kuning yang dibatasi oleh daerah Sub DAS Tunau dan Jelau dengan neraca airtanah sebesar $80.082 \mathrm{~m}^{3}$ hari $^{-1}$. Ketiga, zona hijau yang dibatasi oleh kawasan tambang dengan neraca airtanah sebesar $5.870 \mathrm{~m}^{3}$ hari $^{-1}$. Ketiga zona tersebut pada kondisi alami masih berupa kawasan hutan yang mempunyai nilai limpasan air permukaan kecil dan imbuhan airtanah yang besar.

Hasil kalibrasi head hidrolika observasi dan pemodelan, kemudian diplot pada diagram scatter, memperoleh nilai RMS sebesar 8,875 persen. Nilai ini menjelaskan, terdapat penyimpangan atau deviasi dari hasil model dengan kondisi alami yang masih wajar, yaitu kurang dari 10 persen. Penyimpangan ini disebabkan heterogenitas litologi/akuifer dan variasi konduktivitas hidrolika tiap lapisan akuifer yang mempengaruhi selisih/perbedaan head hidrolika observasi (observed head) dengan pemodelan (calculated head). Diagram scatter head observasi dan pemodelan dapat dilihat pada Gambar 7. 


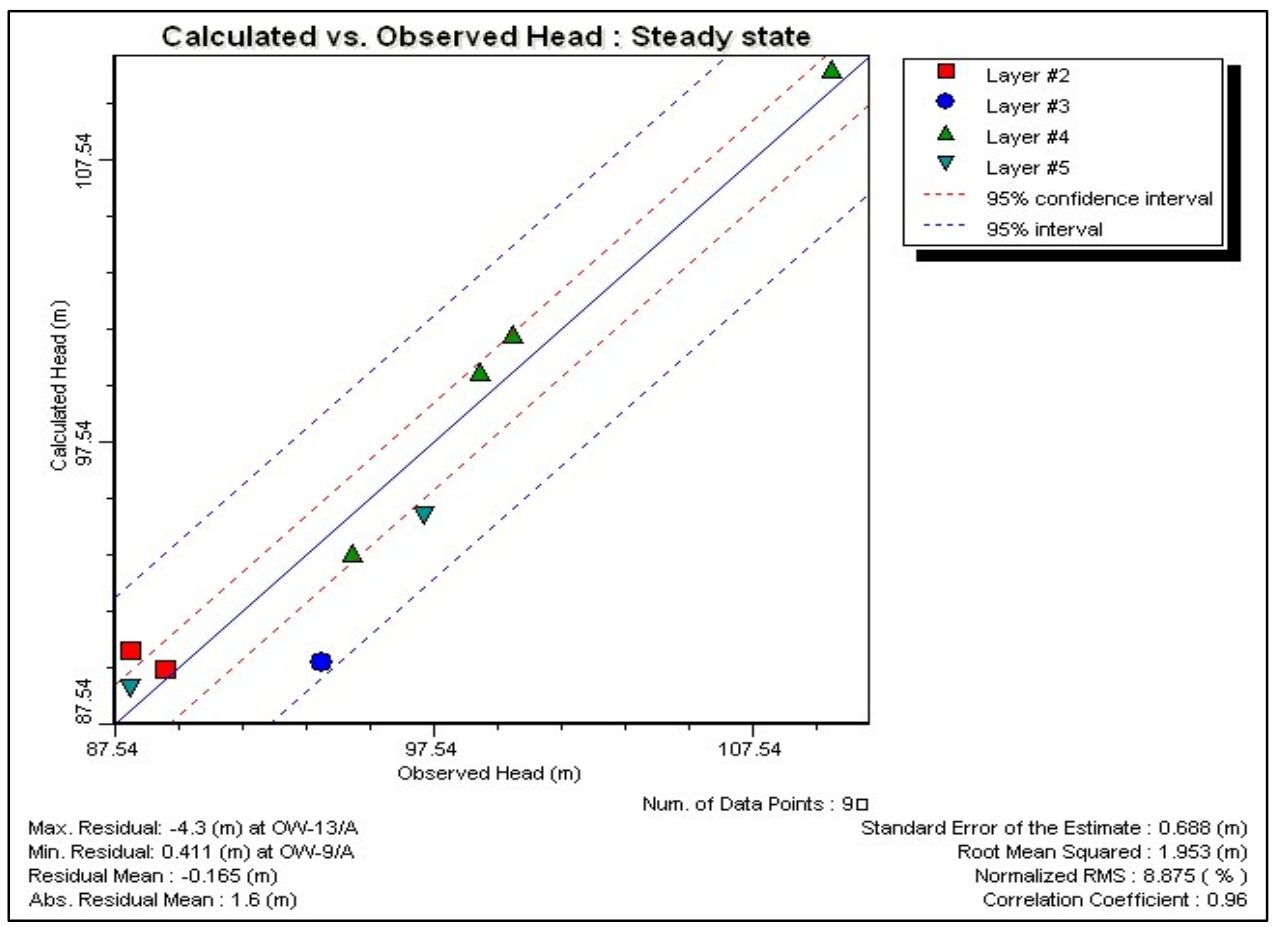

Gambar 7: Diagram Scatter Head Observasi (Observed Head) dan Pemodelan (Calculated Head)

\subsection{Pemodelan Airtanah dan Zona Neraca Airtanah pada Penambangan Aktif Daerah Model Penelitian}

Tabel 4 menjelaskan, terdapat perubahan kedalaman muka airtanah piezometrik yang berkorelasi dengan perubahan head hidrolika, seperti pada sumur observasi bekas lubang bor OW-8 dari $95 \mathrm{~m}$ dpl pada kondisi alami menjadi $58 \mathrm{~m}$ dpl pada penambangan aktif. Tingginya perubahan kedalaman airtanah piezometrik OW-8 pada aktivitas penambangan dibandingkan pada kondisi sebelum penambangan disebabkan berada kawasan tambang aktif.

Tabel 4: Selisih Nilai Head Hidrolika Pemodelan Airtanah Alami dan Penambangan Aktif

\begin{tabular}{ccccccc}
\hline No & $\begin{array}{c}\text { Sumur bor } \\
\text { bekas } \\
\text { pemboran }\end{array}$ & $\begin{array}{c}\text { Elevasi } \\
\text { permukaan } \\
\text { (m dpl) }\end{array}$ & $\begin{array}{c}\text { Kedalaman muka } \\
\text { airtanah } \\
\text { piezometrik }(\mathbf{m})\end{array}$ & $\begin{array}{c}\text { Head- } \\
\text { awal/alami } \\
\text { (m dpl) }\end{array}$ & $\begin{array}{c}\text { Head- } \\
\text { tambang } \\
\text { aktif } \\
\text { (m dpl) }\end{array}$ & $\begin{array}{c}\text { Selisih } \\
\text { head }(\mathbf{m})\end{array}$ \\
\hline 1 & OW-1 & 168 & 60,4 & 109,2 & 107,6 & 1,6 \\
2 & OW-2 & 136,5 & 39,5 & 99,1 & 97 & 2,1 \\
3 & DD-13G & 143,2 & 53,2 & 95,7 & 90 & 5,7 \\
4 & OW-4 & 139,2 & 42 & 100,6 & 97,2 & 3,4 \\
5 & OW-6** & 146,9 & 79,9 & 99,1 & 67 & 32,1 \\
6 & OW-8* & 133,8 & 75,8 & 95 & 58 & 37 \\
7 & OW-9* & 147,1 & 82,1 & 96,1 & 65 & 31,1 \\
8 & OW-10* & 115,1 & 48,1 & 93,6 & 67 & 26,6 \\
9 & OW-13** & 139,2 & 66,2 & 90 & 73 & 17 \\
\hline
\end{tabular}

Keterangan: *) lokasi di daerah pit; **) lokasi di daerah disposal

Hasil pemodelan airtanah dari Gambar 8, memperlihatkan, terdapat tiga kawasan zona neraca airtanah pada penambangan aktif, yang pembagiannya seperti pada zona kondisi alami, yaitu zona putih mempunyai luas $145.500 \mathrm{~m}^{3}$ hari-1 , zona kuning sebesar $88.241 \mathrm{~m}^{3}$ hari-1 , dan zona hijau sebesar 31.241 $\mathrm{m}^{3}$ hari $^{-1}$. 
Berdasarkan hubungan antara ekuipotensial head hidrolika dan letak perlapisan akuifer, yang mengacu hasil pemodelan airtanah pada Gambar 8, dapat diambil kesimpulan, terdapat kecenderungan pola arah aliran airtanah yang mengarah ke pit, yaitu dari ekuipotensial head hidrolika teratas pada lapisan ke-1 hingga ke lapisan ke-4. Kerapatan ekuipotensial head hidrolika yang menurun pada daerah pit mengakibatkan arah aliran airtanah terfokus menuju ke pit. Namun, arah aliran airtanah ke pit kembali pulih pada pada lapisan ke-5 hingga ke-7 akibat adanya lapisan akuitar (lapisan ke-4) yang membatasi/menyekat lapisan ke-3 dan lapisan ke-5. Secara umum, arah aliran airtanah di luar daerah pit yang berasal dari lapisan akuifer pertama hingga terakhir mengalir dari timur ke barat.

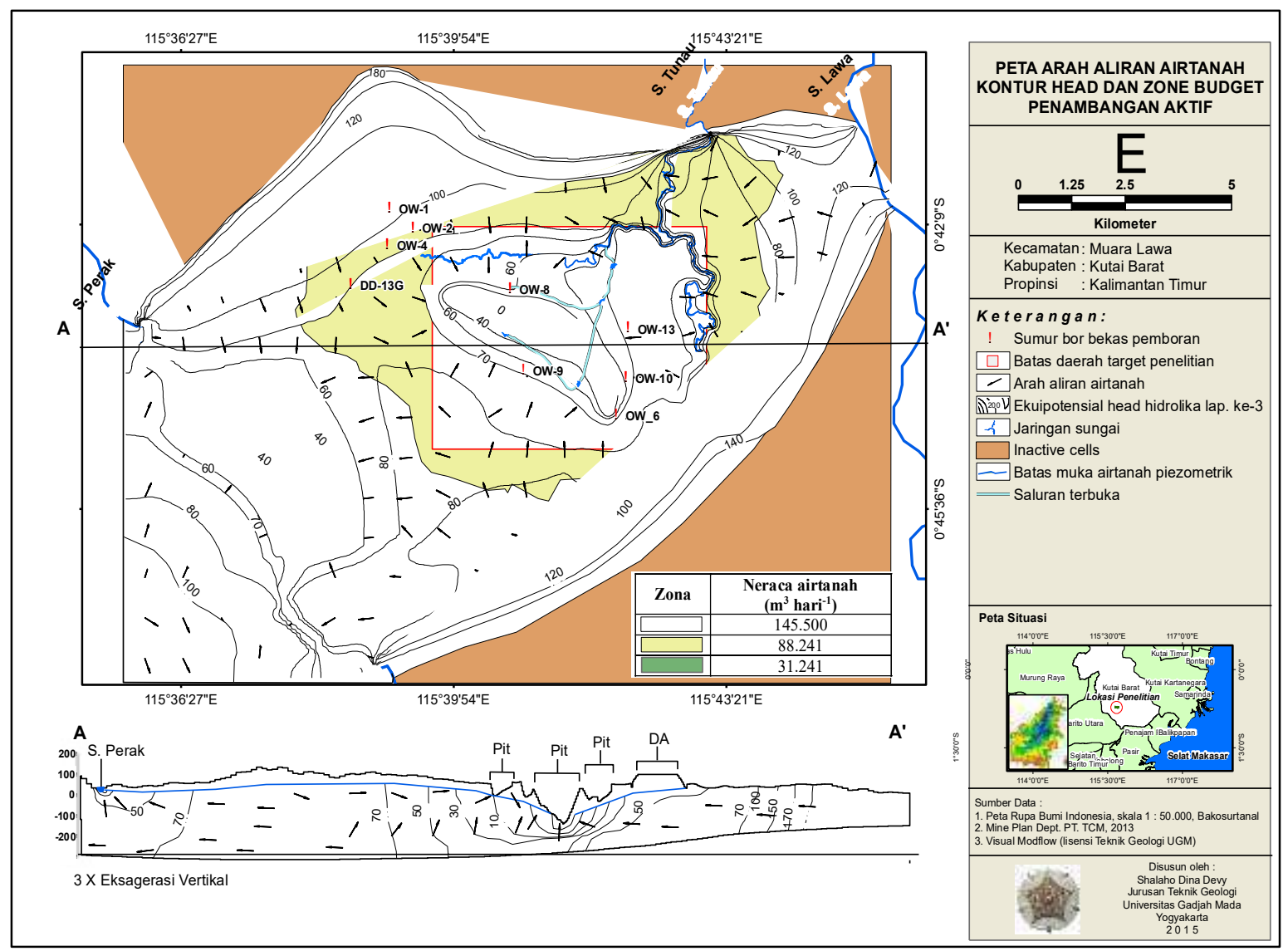

Gambar 8. Pola Aliran Airtanah dan Zona Neraca Airtanah Penambangan Aktif

\section{Kesimpulan}

Hasil pengamatan di lapangan yang kemudian diplotkan dalam peta geologi, memperlihatkan, daerah model penelitian berada di struktur lipatan, yaitu Sinklin Lampanan. Posisi sumbu sinklin berada di antara lapisan batuan utara dan selatan yang mempunyai kemiringan saling berlawanan.

Kecenderungan pola arah aliran airtanah mengarah ke pit, yaitu dari ekuipotensial head hidrolika teratas pada lapisan ke-1 hingga ke lapisan ke-4. Terdapat perubahan kedalaman muka airtanah piezometrik yang berkorelasi dengan perubahan head hidrolika, seperti pada sumur observasi bekas lubang bor OW8 dari $95 \mathrm{~m}$ dpl pada kondisi alami menjadi $58 \mathrm{~m}$ dpl pada penambangan aktif. Tingginya perubahan kedalaman airtanah piezometrik OW-8 pada aktivitas penambangan dibandingkan pada kondisi sebelum penambangan disebabkan berada kawasan tambang aktif.

Selain itu, terjadi kenaikan neraca airtanah hampir lima kali lipat dari kondisi alami ke kondisi penambangan aktif, terutama pada zona hijau, yaitu dari kondisi alami $5.870 \mathrm{~m}^{3}$ hari-1 menjadi 31.241 $\mathrm{m}^{3}$ hari ${ }^{-1}$ pada penambangan aktif. Hal ini disebabkan, zona hijau adalah kawasan tambang terjadi perubahan tata guna lahan dan hidrostratigrafi, yaitu terbentuknya pit yang mencapai kedalaman 70 meter, yang mengakibatkan terpotongnya lapisan akuifer tengah, yang mempunyai penyebaran luas 
dengan ketebalan hingga 21 meter. Lapisan akuifer tengah mayoritas berupa batupasir yang berasal dari satuan perselingan batulanau dan batupasir Pulaubalang. Akibat terpotongnya lapisan akuifer ini mengakibatkan turunnya tekanan hidrolika dan pengaruh dari gaya gravitasi yang menyebabkan debit aliran airtanah menjadi besar. Sementara itu, pada zona kuning dan putih terjadi kenaikan neraca airtanah secara wajar, yaitu rata-rata kenaikan dua kali lipat, yang disebabkan penurunan imbuhan airtanah dari kondisi alami sebesar $935,27 \mathrm{~mm} \mathrm{th}^{-1}$ menjadi $601,71 \mathrm{~mm} \mathrm{th}^{-1}$ pada penambangan aktif.

\section{Ucapan Terima Kasih}

Penulis menyampaikan terimakasih kepada PT. Trubaindo Coal Mining tbk daerah operasi penambangan Muara Lawa di Kutai Barat, Provinsi Kalimantan Timur, yang telah memberikan bantuan teknis, supervisi, dan nonteknis untuk operasional penelitian lapangan, sehingga penelitian ini selesai sesuai dengan target rencana yang diharapkan.

\section{Daftar Pustaka}

Arsyad, S., 1989, Konservasi Tanah dan Air, IPB Press, Bogor, hlm 85-86

Asdak, C., 1995, Hidrologi dan Pengelolaan Daerah Aliran Sungai, Gadjah Mada University Press, Yogyakarta, hlm. $154-210$.

Hammer, M.J. and Mac-Kichen, K.A., 1981, Hydrology and Quality of Water Resources, John Wiley \& Sons, Ltd., New York, $p .41,140,214$

Healy, R., W. and Cook Peter, G., 2002, Using Groundwater Levels to Estimate Recharge, Hydrogeology Journal, Vol. 10, No. 1, p. $91-107$.

Irawan, D.E., Puradimaja, D.J., 2013, Lembar Kerja Hidrogeologi Umum, Kelompok Keahlian Geologi Terapan Fakultas Ilmu dan Teknologi Kebumian Institut Teknologi Bandung

Kabupaten Kutai Barat dalam Angka, 2011, BPS Kabupaten Kutai Barat

Kamiana, I., 2010, Teknik Perhitungan Debit Rencana Bangunan Air, Graha Ilmu, Yogyakarta, hlm. 28-30, 203

Lerner, D.N., 1990, Groundwater recharge in Urban Areas, Hydrological Processes and Water Management in Urban Area, Proceedings of the Duisberg Symposium, April 1990, IAHS Publ., No. 198

Mandel, S., Shiftan, Z.L., 1981, Groundwater Resources: Investigation and Development, Academic Press. Inc, USA

Notodarmojo, S., 2005, Pencemaran Tanah dan Airtanah, Penerbit ITB, Bandung.

Puradimaja, D.J., 1993, Penyusunan Tipologi Paket Penelitian Sumber Daya Air, LAPI ITB-Departmen Transmigrasi, Bandung

Seiler, K.P., Gat, J.R., 2007, Groundwater Recharge from Run-Off, Infiltration and Percolation, Springer, The Netherland, $p .75$

Supriatna, S., Sukardi, Rustandi, 1995, Peta Geologi Bersistem, Lembar Samarinda, Kalimantan sekala 1:250.000, Pusat Penelitian dan Pengembangan Geologi Bandung.

Van Bemmelen, R.W., 1949, The Geology of Indonesia, Government Printing Office, the Hague, Netherland, p. $328-360$. 